\title{
Effects of Livestock Grazing on Infiltration Rates, Edwards Plateau of Texas
}

\author{
G.R. MCCALLA I, W.H. BLACKBURN, AND L.B. MERRILL
}

\begin{abstract}
The influence of short duration graxing (SDG), moderate continuous grazing (MCG), heavy continuous grazing (HCG), and graxing exclusion on infiltration mates of midemessend hortgredominated communities was evaluated over a 20 -month period on the Texas Agricultural Research Station, located near Sonora in the Edwards Plateau, Texas. A combination of cattle, sheep, and goats were used in each grazing treatment. Infiltration rates were consistently less in the midgrass (bunchgrass) than in the shortgrass (sodgrass) community. The HCG pasture was severely overgrazed and infiltration rates were reduced to about one-half those in the MCG pasture. The midgrasses in this pasture were destroyed after 26 months of overgrazing. Infiltration rates in the SDG pasture, stocked at double the recommended rate, decreased during the study period. Infiltration rates in the SDG pasture shortgrass community, near the end of the study, approached those in the HCG pasture. The greatest infiltration rates for both communities were maintained in the MCG pasture. Infiltration rates for the midgrass community remained relatively stable during the study when the general trend in the SDG and HCG pastures was toward reduced infiltration rates. The nongrazed pasture subsequent to the $\mathbf{1 9 8 0}$ drought had a general increase in infiltration rates.
\end{abstract}

Infiltration rates vary naturally in time and space because of normal variations in climate, vegetation, and intensity and duration of livestock use. Few studies have attempted to account for these natural variations. The literature is filled with examples of the adverse impact of heavy or abusive grazing on infiltration rates. Few research projects have studied seasonal or long-term impacts of grazing systems or proper grazing management on infiltration rates (Blackburn et al. 1982).

Much interest has been generated by specialized grazing systems and their potentials. Short duration grazing and its potential economic benefits to the ranching industry have become extremely popular (Savory 1978). Little information is available, however, to support many of the claims concerning specialized grazing systems. Gifford and Hawkins (1978) found no published evidence to show that any single grazing system consistently or significantly increased plant and litter cover on watersheds. Other reviews (Van Pollen and Lacey 1979, Beck 1980) of the impacts of grazing support Gifford and Hawkins' conclusions. Most of the information on the impact of specialized grazing systems on infiltration rates come from studies conducted in the Rolling Plains and Edwards Plateau of Texas. The results of these studies indicate that infiltration rates of pastures grazed under a deferred-rotation system (4-3:12:4 mo $)^{1}$ were similar to those of livestock exclosures and greater than high intensity, low frequency pastures (8-1:17:119 days) or moderate or heavy continuously grazed pastures (McGinty

\footnotetext{
Authors are graduate research assistant and professor of watershed management Range Science Department, Texas A\&M University, College Station 77843; and professor of Range Science, Texas Agricultural Experiment Station, Sonora 76950. Published with approval of the Director, Texas Agricultural Experiment Station, as TA-18727.

Manuscript received May 31, 1983.
}

'Nomenclature follows Kothmann 1974. et al. 1978, Wood and Blackburn 1981). Infiltration rates of pastures grazed under a high intensity, low frequency system were similar to moderate continuously grazed pastures (Wood and Blackburn 1981, Blackburn et al. 1982).

Livestock grazing can alter infiltration rates of rangeland soils by removing protective plant cover and by trampling. Vegetation and mulch cover serve to protect the soil surface from raindrop impact and influence soil surface properties such as bulk density, organic matter content, and aggregation (Osborn 1954, Copeland 1963, Blackburn 1975, Meeuwig and Packer 1976, Blackburn et al. 1982). Reduced infiltration rates as a result of livestock grazing have been attributed to: () loss of vegetation cover, (2) decreased mulch cover, (3) decreased amounts of vegetation standing crop and mulch, (4) increased bare ground, and (5) increased bulk density as a result of trampling (Alderfer and Robinson 1947, Knoll and Hopkins 1959, Reed and Peterson 1961, Branson et al. 1962, Copeland 1963, Dee et al. 1966, Rauzi and Hanson 1966, Smith 1967, Blackburn et al. 1982). Type of vegetation is important in determining infiltration rates (Blackburn 1975). Infiltration rates are consistently higher in bunchgrass-dominated areas than in sodgrass-dominated areas (Blackburn et al. 1980, Wood and Blackburn 1981). Livestock grazing has the greatest potential impact on bunchgrasses. Not only are bunchgrasses usually the better forage species but they are usually more sensitive to heavy grazing pressure than low-growing sodgrasses (Wood and Blackburn 1981). Objectives of this study were to determine: (1) infiltration rates of pasture soils under short duration grazing; moderate continuous grazing; and heavy continuous grazing; and grazing exclusion; and (2) the variables influencing infiltration.

\section{Study Area}

Research was conducted on the Texas Agricultural Research Station, located near Sonora in the Edwards Plateau, Texas. The 1,404-ha station lies on the boundary separating Sutton and Edwards counties. Station elevation is approximately $632 \mathrm{~m}$ with an average growing season of $\mathbf{2 4 0}$ days.

The Edwards Plateau is second only to the Trans-Pecos region of Texas in length and frequency of drought (Sprott 1971). Precipitation was highly variable and poorly distributed $(428 \mathrm{~mm})$ in 1980 , especially during the growing season, while 1981 had above-average precipitation ( $556 \mathrm{~mm}$ by August). No precipitation was recorded in July 1981 and the greatest precipitation $(171 \mathrm{~mm})$ occurred in the preceding month, June 1981 . Average precipitation for the station is $553 \mathrm{~mm}$ annually (TDWR 1982).

The study site soils are Tarrant silty clays which are members of the clayey-skeletal, montmorillonitic, thermic family of Lithic Haplustalls. The slopes are gentle $(<3 \%)$. Vegetation of the study area at the beginning of this project was characterized by oak mottes and grass-dominated interspaces. The grass interspaces were dominated by either mid- or shortgrasses. Grasses on the study site included common curlymesquite (Hilaria belangeri (Steud.) Nash) the dominant sodgrass, threeawn (Aristida spp.), sideoats grama (Bouteloua curtipendula (Michx.) Torr.) the dominant bunchgrass, Texas wintergrass (Stipa leucotricha Trin. \& 
Rupr.), bluestems (Andropogon spp., Bothriochloa spp., Schizachyrium spp.), and hairy grama (Bouteloua hirsuta Lag.). Dominant woody plants are live oak (Quercus virginiana Mill. var. virginiana), honey mesquite (Prosopis glandulosa Torr.), and ashe juniper (Juniperus asheii Buchh.).

Three grazing regimes: (1) heavy continuous grazing (HCG), (2) moderate continuous grazing (MCG), and (3) short duration grazing (SDG) (14-1;4:50 day) were studied to evaluate the impacts of livestock grazing on selected hydrologic variables. An adjacent nongrazed pasture was added (March 1980) to evaluate recovery from livestock exclusion. The 3 grazed pastures were 6 ha in size and the nongrazed area was 3.5 ha. The HCG pasture was in low-fair range condition at the beginning of this study (January 1980). The MCG, SDG, and nongrazed pastures were in fair to high-fair condition (USDA 1972). A combination of cattle, sheep, and goats was used in each grazing treatment approximating the recommended animal unit ratio of $50: 25: 25$, respectively, used on the Edwards Plateau.

The SDG pasture was under a high-intensity, low-frequency (HILF) (8-1:17:119 days) grazing system prior to the SDG treatment (March 1978-December 1980). It was continuously grazed at a moderate stocking rate, approximately $8.1 \mathrm{ha} / \mathrm{AU} / \mathrm{yr}$, previous to the HILF system. The SDG pasture simulted 1 pasture of a 14-pasture, 1-herd grazing system, with approximately a 4-day and 50-day graze/ rest cycle. Stocking rates varied from $3.2 \mathrm{ha} / \mathrm{AU} / \mathrm{yr}$ to $4.9 \mathrm{ha} / \mathrm{AU} / \mathrm{yr}$ because of destocking during the $1980 \mathrm{drought}$. The MCG pasture was historically grazed at $8.1 \mathrm{ha} / \mathrm{AU} / \mathrm{yr}$.

Stocking rate on the $\mathrm{HCG}$ pasture varied in accordance with changes in forage production and livestock breeding season and this pasture was grazed most intensively at the beginning of the study. Stocking rate ranged from $0.3 \mathrm{ha} / \mathrm{AU} / \mathrm{yr}$ to $12 \mathrm{ha} / \mathrm{AU} / \mathrm{yr}$. This pasture has been extremely heavily grazed since March 1978, but previously was under MCG.

The nongrazed pasture was fenced in February 1980 to exclude livestock and was first sampled in March 1980. Previous grazing history was MCG. This pasture has a greater slope and stonier and shallower soil than the other pastures in the study. This difference was large enough to prevent direct comparison with the grazed pastures, however, recovery of watershed variables from livestock grazing can be evaluated.

\section{Methods}

\section{Infiltration}

Infiltration rates were determined with a drip-type rainfall simulator (Blackburn et al. 1974) on eight $0.5-\mathrm{m}^{2}$, randomly located runoff plots in each vegetation type and treatment for each of the 11 sample dates during 1980 and 1981 . The runoff plots were pre-wet with $120 \mathrm{l}$ of water using a sprinkler system to remove antecedent soil-water content differences and covered with clear plastic to maintain uniform surface water conditions. After the runoff plots drained to field capacity (approximately $24 \mathrm{hr}$ ), simulated rainfall was applied at a rate of $20.8 \mathrm{~cm} / \mathrm{hr}$ for $0.5 \mathrm{hr}$. This application rate approximates a storm with return period of 150 years and was necessary to ensure runoff from all plots. Runoff was continuously collected and weight measurements were made at 5-minute intervals. Infiltration rates were determined by calculating the difference in applied simulated rainfall and runoff from each plot.

\section{Vegetative Cover, Standing Crop and Mulch}

The percentage ground covered by midgrass, shortgrass, and forb foliage, and mulch, rock, and bare ground were determined by ocular estimates on each runoff plot from a gridded sampling quadrat. Grasses, forbs, and standing dead material were clipped to a 2-cm stubble height and mulch was hand-collected from each runoff plot. The herbaceous material was dried at $60^{\circ} \mathrm{C}$ for $48 \mathrm{hr}$ and weighed.

Soils

Immediately before each simulated rainfall event, soil bulk den- sity and soil water content adjacent to each runoff plot for depths of 0 to $3 \mathrm{~cm}$ and 5 to $8 \mathrm{~cm}$ were determined by the core method (Black 1965) and the gravimetric method (Gardner 1965), respectively. A soil sample was collected from $0-3 \mathrm{~cm}$ within each plot after the simulated rainfall event and analyzed for organic matter by the Walkley-Black method (Walkley and Black 1934), aggregate stability by the wet sieve method (Kemper and Koch 1965), and texture by the hydrometer method (Bouyoucos 1962). Surface roughness within each plot was measured with a relief meter similar to the one described by Kincaid and Williams (1966) but consisting of 10 evenly spaced pins.

\section{Analysis}

Data normality was determined by tests for skewness and kurtosis (Snedecor and Cochran 1971). Values for surface roughness were highly skewed requiring a $\log 10$ transformation of the data set. Differences between vegetation communities and treatment differences by vegetation community were determined by analysis of variances. Within treatment variation (variation among subplots) was allocated to the residual for testing differences $(P<.05)$ among treatments. Treatment means were separated by Duncan's multiple range test (Steele and Torrie 1980). Simple linear correlation and forward stepwise multiple regression analysis were used to determine degree of association and to identify the most important factors determining infiltration rates (Draper and Smith 1981).

\section{Results and Discussion}

\section{Infiltration Rates}

Mean infiltration rates were determined after a period of $5,10,15$, 20,25 , and 30 minutes. Because of similarity of the data for the different time periods, only mean infiltration rate after $\mathbf{3 0}$ minutes will be discussed.

Infiltration rates (Fig. 1) were significantly greater for the midgrass-dominated community than for the shortgrass-dominated

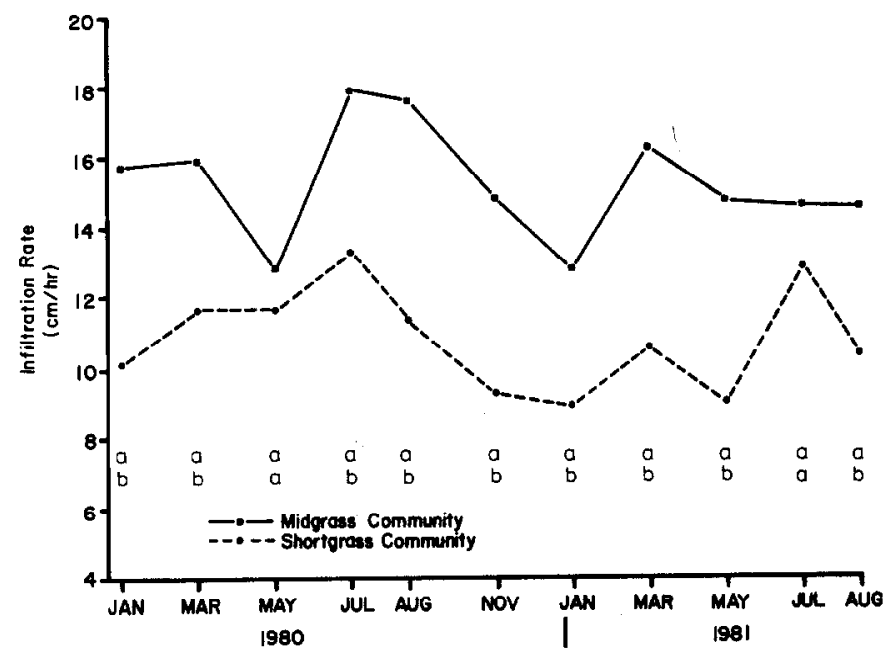

Fig. 1. Mean infiltration rates after 30 minutes by plant community and sample date, Edwards Plateau, Texas. Means for each sample date with the same letter are not significantly different $(\mathrm{P} \leq 05)$.

community except for May 1980 and July 1981. The greatest infiltration rates in the shortgrass community were observed in July 1980 and 1981 , while the greatest infiltration rates in the midgrass communities occurred in July and August 1980. Infiltration rates were lowest in May 1980 and January 1981 for the midgrass community and January and May 1981 for the shortgrass community. Infiltration of both communities exhibited a general annual cyclic pattern with the greater rates occurring during the growing season and the lowest during the dominant season. Although a seasonal infiltration pattern was less defined in the midgrass community, infiltration rates were generally greatest in both communities during peak biological activity. 


\section{Midgrass Community}

Infiltration rates of the HCG pasture (Fig. 2) were significantly lower than the MCG or SDG pastures in January, March, and May of 1980. There was a nonsignificant trend for infiltration rates
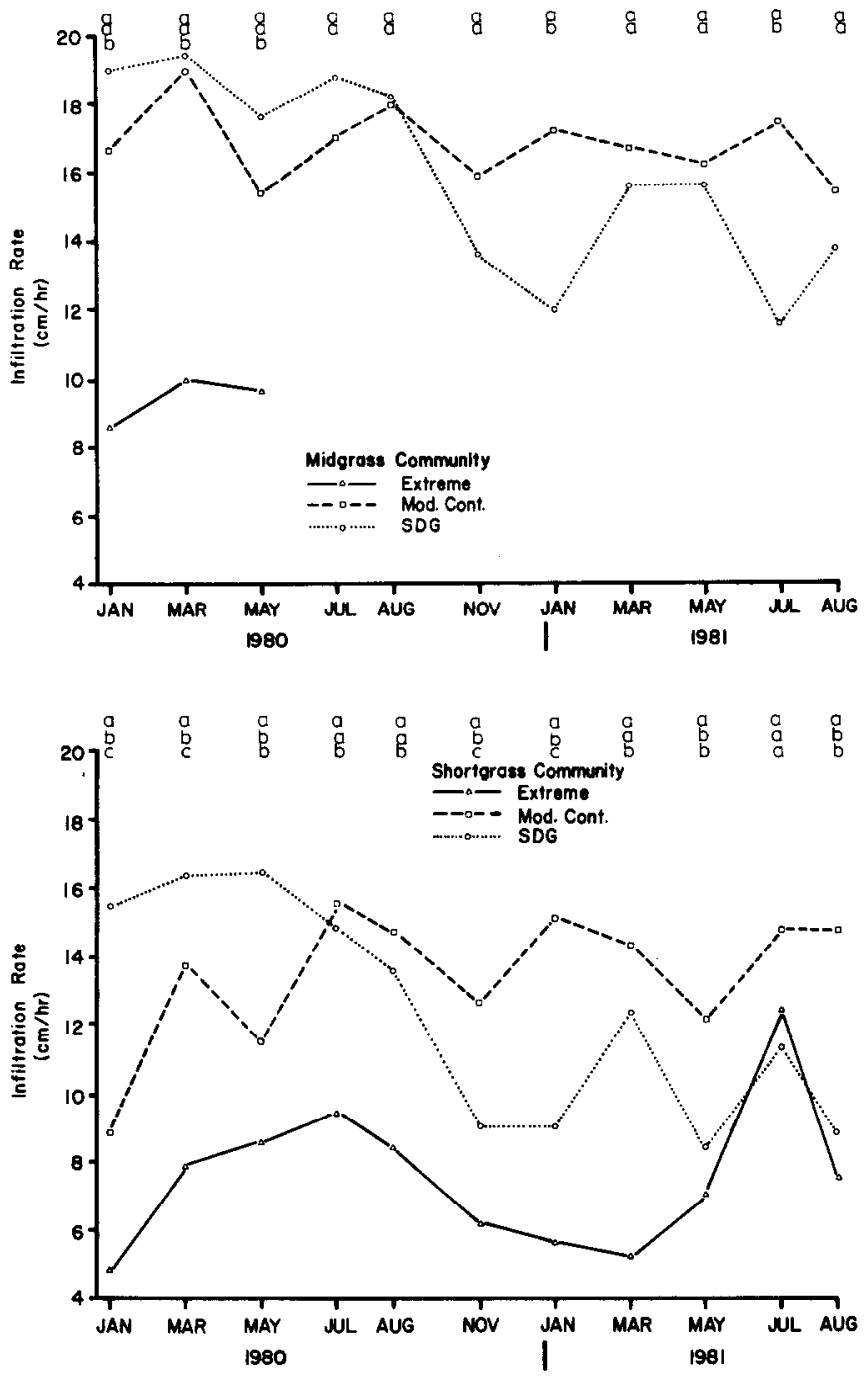

Fig. 2. Mean infiltration rates after 30 minutes for midgrass or shortgrass community by sample date and livestock grazing treatment, Edwards Plateau, Texas. Means for each sample date with the same letter are not significantly different ( $\mathrm{P} \leq .05)$.

in the SDG pasture to be greater than the MCG pasture through August 1980. However, this nonsignificant trend reversed in November 1980 when infiltrates in the SDG pasture were less than those of the MCG pasture. The trend remained for the remainder of the study with infiltration rates in the SDG pasture being significantly lower than the MCG pasture in January and July 1981.

Infiltration rates in the non-grazed pasture were highly variable (Fig. 3) and tended to be lower than those in the MCG or SDG pastures because of site differences until August 1981 when increased infiltration rates were attributed to increased plant and mulch cover.

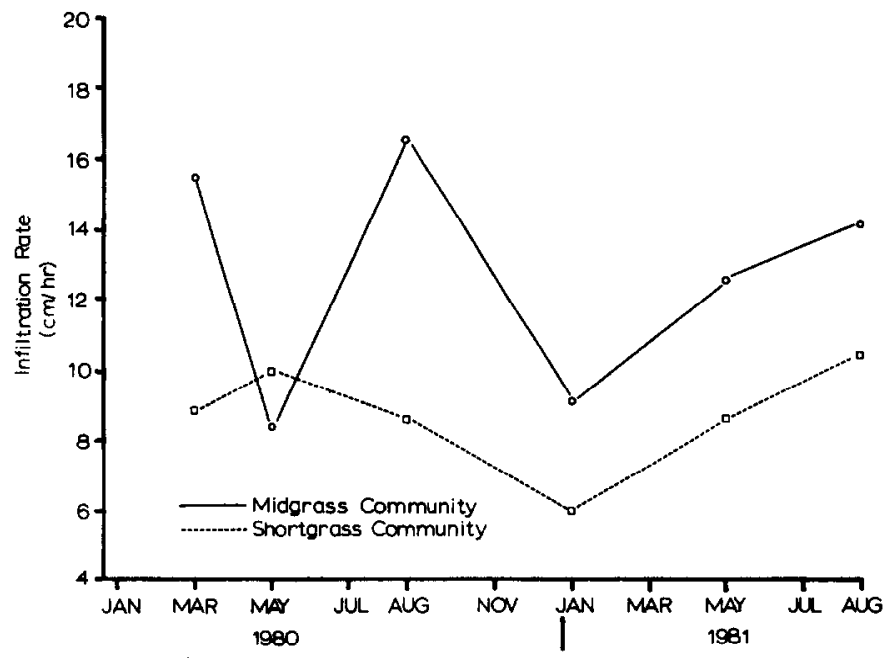

Fig. 3. Mean infiltration rate after 30 minutes for the non-grazed pasture by plant community and sample date, Edwards Plateau, Texas.

Infiltration rate decreases were greater in the SDG pasture than in the MCG pasture during the study period but were significantly lower only during January and July 1981.

\section{Shortgrass Community}

Infiltration rates were significantly lower in the HCG pasture than in the MCG or SDG pastures for all sample dates except May 1980 and July 1981 in the MCG pasture and July 1981 in the SDG pasture. Infiltration rates in the HCG pasture were greatest in July of both years and smallest during January 1980 and March 1981 . Infiltration rates were significantly greater in the SDG pasture than in the MCG pasture for the first 3 sample dates. In July 1980 , however, they were less but not significantly different from rates in the MCG pasture. A strong downward trend continued throughout the remainder of the study. Infiltration rates in the SDG pasture were significantly less than those in the MCG pasture in November 1980 and January, May, and August of 1981 and showed a trend approaching the infiltration rates of the HCG pasture.

Infiltration rates in the nongrazed pasture decreased from May 1980 through January 1981, after which a steady increase occurred (Fig. 3). Infiltration rates in the nongrazed pasture were similar to those in the HCG pasture for all sample dates, but less than in the

Table 1. Multiple regression equations and coefficient of determination for six different infiltration time periods, Edwards Platesu, Texas.

\begin{tabular}{ccc}
\hline \hline $\begin{array}{c}\text { Infiltration } \\
\text { rate } \\
\text { after }\end{array}$ & Regression equation & $\begin{array}{c}\text { Coefficient of } \\
\text { determination } \\
\left(R^{2}\right)\end{array}$ \\
\hline $5 \mathrm{~min}$ & $\mathrm{Y} 1=22.272-2.860 \mathrm{BD}+0.001 \mathrm{GSC}-0.038 \mathrm{BG}-0.076 \mathrm{RC}$ & 0.40 \\
$10 \mathrm{~min}$ & $\mathrm{Y} 2=22.413-4.136 \mathrm{BD}+0.002 \mathrm{GSC}-0.064 \mathrm{BG}-0.104 \mathrm{RC}$ & 0.49 \\
$15 \mathrm{~min}$ & $\mathrm{Y3}=22.015-4.584 \mathrm{BD}+0.002 \mathrm{GSC}-0.070 \mathrm{BG}-0.108 \mathrm{RC}$ & 0.51 \\
$20 \mathrm{~min}$ & $\mathrm{Y} 4=22.584-4.754 \mathrm{BD}+0.002 \mathrm{GSC}-0.074 \mathrm{BG}-0.114 \mathrm{RC}$ & 0.52 \\
$25 \mathrm{~min}$ & $\mathrm{YS}=22.596-5.174 \mathrm{BD}+0.002 \mathrm{GSC}-0.073 \mathrm{BG}-0.108 \mathrm{RC}$ & 0.52 \\
$30 \mathrm{~min}$ & $\mathrm{Y} 6=21.162-5.109 \mathrm{BD}+0.002 \mathrm{GSC}-0.074 \mathrm{BG}-0.109 \mathrm{RC}$ & 0.52 \\
\hline
\end{tabular}

'HD = Bulk Density

GSC $=$ Grass Standing Crop

BG = Bare Ground

RC = Rock Cover 
MCG pasture except for May 1980 and less than in the SDG pasture except for May 1981.

Infiltration rates in the MCG and nongrazed pastures tended to increase during the study where the SDG pasture showed a downward trend. A 119-day rest period associated with a prior HILF grazing treatment on the site probably delayed the reduced infiltration rates exhibited by SDG, subsequently installed on the site. Infiltration rates in the SDG pasture were less than those of the MCG pasture 1 sample period earlier (July 1980) in the shortgrass community than in the midgrass community (August 1980).

\section{Factors Influencing Infiltration Rates}

The strongest simple correlations occurred with the mean infiltration rate after 30 minutes. The variables that exercised the greatest influence on infiltration rates were total vegetation cover $(r=0.57)$, grass standing crop $(r=0.56)$, midgrass cover $(r=0.55)$, surface roughness ( $r=0.53$ ), bare ground $(r=0.48)$, bulk density $0-3$ $\mathrm{cm}(r=-0.42)$, aggregate stability $(r=0.37)$, soil organic matter $(r=0.30)$, and rock cover $(r=-0.31)$. Midgrass cover accounted for $30 \%$ of the variations in infiltration rates and was one of the stronger influencing variables. Shortgrass $(r=-0.10)$ and forb $(r=-0.10)$ cover, however, account for only $1 \%$ of the variation in infiltration rates and were negatively related to infiltration.

Predictive equations with infiltration rate as a dependent variable were determined by forward stepwise multiple regression analysis. The same four variables occurred in the same order of importance for the six different infiltration time periods (Table 1). Bulk density, 0-3 cm depth, was the most important variable, followed in order of importance by grass standing crop, bare ground, and rock cover.

\section{Conclusions}

Infiltration rates in the midgrass (bunchgrass) community averaged $40 \%(4.4 \mathrm{~cm} / \mathrm{hr})$ greater than in the shortgrass (sodgrass) community. A decline in midgrasses, regardless of the cause, will eventually result in lower infiltration rates and soil water for plant growth thus lowering the watershed condition of the site. Livestock grazing potentially have the greatest impact on midgrasses. They are usually the better forage species and are generally more sensitive to abuse than the shortgrasses. Twenty-six months of HCG destroyed the midgrasses and had such an adverse impact on vegetation and soil parameters that infiltration rates were reduced to about one-half those in the MCG pasture. Midgrasses are easily destroyed by overstocking and should be monitored closely when: (1) stocking rates are changed, (2) new grazing systems are initiated, or (3) during drought.

Infiltration rates in the SDG pasture stocked at double the recommended rate decreased during the study period. The shortgrass community reflected adverse impacts of SDG on infiltration rates after 6 months whereas the midgrass community reflected adverse effects after 8 months. Infiltration rates from the shortgrass community approached those of the HCG pasture near the end of the study. The combination of SDG and drought had an adverse impact on infiltration rates in hoth communities. Although stocking rates were decreased to 4.9 ha/ AU yr during the 1980 drought, the low infiltration rate in the SDG pasture during November 1980 and 1981 was attributed to poor growing conditions during the summer and fall of 1980 . Little plant regrowth occurred during the rest period prior to the November or January sample periods. Results strongly suggest that if most of the additional carrying capacity with a SDG system can not be obtained by increasing livestock distribution as a result of fencing and water development, then extreme caution should be used in adjusting stocking rates upward.

The greatest infiltration rates for both communities were maintained in the MCG pasture. Infiltration rates for the midgrass community remained relatively stable during the study when the general trend in the SDG and HCG pastures were toward reduced infiltration rates. This data strongly suggests that watershed condition can be maintained or improved under MCG.

The nongrazed pasture had a large enough site difference to prevent direct comparison with the grazed pastures. The nongrazed pasture subsequent to the 1980 drought had a general increase in infiltration rates in both the midgrass and shortgras communities.

Variables influencing infiltration rates include total vegetation cover, grass standing crop, midgrass cover, bulk density, bare ground, surface roughness, aggregate stability, organic matter and rock cover. The most important multiple regression variables were bulk density, grass standing crop, bare ground, and rock cover.

\section{Literature Cited}

Alderfer, R.B., and R.R. Robinson. 1947. Runoff from patures in relation to grazing intensity and soil compaction. Amer. Soc. Agron. J. 29:948-958.

Beck, R.F. 1980. Impacts of grazing systems on range vegetation. Proc., Grazing Management Systems for Southwest Rangelands Symp. New Mexico State Univ., Las Cruces.

Black, C.A. (ed.). 1965. Methods of soil analysis. Amer. Soc. of Agron. Series No. 9. Madison, Wis.

Blackburn, W.H. 1975. Factors influencing infiltration and sediment production of semiarid rangelands in Nevada. Water Resour. Res. 11:929-937.

Blackburn, W.H. 1983. Livestock grazing impacts on watersheds. Rangelands 5:123-125.

Blackburn, W.H., R.W. Knight, and M.K. Wood. 1982. Impact of grazing on watersheds: a state of knowledge. Texas Agr. Exp. Sta. Pub. MP-1496.

Blackburn, W.H., R.W. Knight, M.K. Wood, and L.B. Merrill. 1980. Watershed parameters as influenced by grazing. Proc. Symp. on Watershed Management. Amer. Soc. Civil Eng. Boise, Ida.

Blackburn, W.H., R.0. Meeuwig, and C.M. Skau. 1974. A mobile infiltrometer for use on rangeland. J. Range Manage. 27:322-323.

Bouyoucos, G.J. 1962. Hydrometer method improved for making particle size analysis of soil. Agron. J. 54:464-465.

Branson, F.A., R.F. Miller, and J.S. McQueen. 1962. Effects of contour furrowing, grazing intensities and soils on infiltration rates, soil moisture and vegetation near Ft. Peck, Mont. J. Range Manage. 15:151-158.

Copeland, O.L., Jr. 1963. Land use and ecological factors in relation to sediment yields. In: Proc., Fed. Interagency Sedimentation Conf., USDA Misc. Pub. 980:72-84.

Dee, R.F., T.W. Box, and E. Robertson, Jr. 1966. Influence of grass vegetation on water intake of Pullman silty clay loam. J. Range Manage. 19:77-79.

Draper, N.R., and H. Smith. 1981. Applied Regression Analysis. John Wiley and Sons, Inc., New York, N.Y.

Gardner, W.H. 1965. Water Content. In:C.A. Black (ed.), Methods of Soil Analysis. Amer. Soc. Agron. Series No. 9. Madison, Wis.

Giffurd, G.F., and R.H. Hawkins. 1978. Hydrologic impact of grazing on infiltration: a critical review. Water Resour. Res. 14:304-313.

Kemper, W.D., and E.J. Koch. 1965. Aggregate stability of soils from the western portions of the U.S. and Canada. USDA Tech. Bull.

Kincaid, D.R., and G. Williams. 1966. Rainfall effects on soil surface characteristics following range improvements. J. Range Management. 19:346-351.

Knoll, G., and H.H. Hopkins. 1959. The effect of grazing and trampling upon certain soil properties. Trans. Kansas Acad. Sci. 62:221-231.

Kothmann, M.M. 1974. Grazing management terminology. J. Range Manage. 27:326-327.

McGinty, W.A., F.E. Smeins, and L.B. Merrill. 1978. Influence of soil, vegetation and grazing management on infiltration rate and sediment production of Edwards Plateau rangeland. J. Range Manage. 32:33-37.

Meeuwig, R.0., and P.E. Packer. 1976. Erosion and runoff on forest and rangelands. p. 106-116.In: Proc. of the Fifth Workshop of the United States/Australia Rangelands Panel, Boise, Ida. June 15-22, 1975.

Osborn, B. 1954. Soil splash by raindrop impact on bare soils. J. Soil and Water Conser. 9:33-38.

Rauzi, F., and C.L. Hanson. 1966. Water intake and runoff as affected by intensity of grazing. J. Range Manage. 19:351-356.

Reed, M.J., and R.A. Peterson. 1961. Vegetation, soil and cattle responses to grazing on Northern Great Plains range. USDA Tech. Bull. 1252. 
Savory, A. 1978. A holistic approach to range management using short duration grazing. p. 555-557. In: D.N. Hyder (ed.), Proc., First Int. Rangeland Cong., Society for Range Manage.

Smith, D.R. 1967. Effects of cattle grazing on a ponderosa pine-bunchgrass range in Colorado. USDA Tech. Bull. 1371.

Snedecor, G.W., and W.G. Cochran. 1971. Statistical Methods. Iowa State Univ. Press, Ames.

Sprott, J.M. 1971. Texas droughts during the 20th century. Chapter 1. Beef Cattle Management During Drought. Texas Agr. Ext. Serv. Pub. B-1108.

Steele, R.G.D., and J.H. Torrie. 1980. Principles and Procedures of Statistics. McGraw-Hill Book Co., Inc. New York, N.Y.
Texas Department of Water Resources. 1982. Climatic data for Sonora Experiment Station. Mimeo.

United States Department of Agriculture. 1972. Range condition classification. Mimeo.

Van Poolen, H.W., and J.R. Lacey. 1979. Herbage response to grazing systems and stocking intensity. J. Range Manage. 32:250-253.

Walkley, A., and A.I. Black. 1934. An examination of the Deqtjareff method for determining soil organic matter and a proposed modification of the chromic acid titration method. Soil Sci. 37:29-38.

Wood, M.K., and W.H. Blackburn. 1981. Grazing systems: their influence on infiltration rates in the Rolling Plains of Texas. J. Range Manage. 34:311-335. 